TILTAI, 2015, 1, 63-82, ISSN 1392-3137 (Print), ISSN 2351-6569 (Online)

\title{
SANTYKIŲ RINKODAROS DIMENSIJŲ RAIŠKA
}

\author{
Deimena Kiyak, Arina Medvedeva \\ Klaipedos universitetas
}

\begin{abstract}
Anotacija
Straipsnyje atskleidžiama santykių rinkodaros koncepcijos esmė ir pagrindinès santykių rinkodaros dimensijos: pasitikèjimas, ịsipareigojimas, abipusė priklausomybė, tarpusavio sąveika, bendradarbiavimas, galia, komunikacija, pasitenkinimas, vertè, teisingumas ir empatija. Sudarytas vartotojų ir asmens sveikatos priežiūros įstaigų tarpusavio santykių palaikymo teorinis modelis, kuriame konstatuojama, kad tiesioginę įtaką vartotojų lojalumui asmens sveikatos priežiūros rinkoje turi pasitikèjimas, įsipareigojimas ir pasitenkinimas. Santykių rinkodaros principai - tarpusavio sąveika ir galia - asmens sveikatos priežiūros rinkoje tik iš dalies lemia vartotojų lojalumą.

PAGRINDINIAI ŽODŽIAI: santykių rinkodara, santykių rinkodaros dimensijos.
\end{abstract}

\begin{abstract}
The article reveals the essence of the concept of relationship marketing and relationship marketing major dimensions: trust, commitment, mutual dependence, reciprocity, cooperation, power, communication, satisfaction, value, fairness and empathy. Composed relationships between consumers and health care institutions support theoretical model which states that a direct effect on customer loyalty in individual health care market has confidence, commitment and satisfaction. Relationship marketing principles - interoperability and power - in personal care market only partially determines the consumer loyalty.

KEY WORDS: relationship marketing, relationship marketing dimensions.
\end{abstract}

DOI: http://dx.doi.org/10.15181/tbb.v69i1.1051

\section{Ivadas}

Asmens sveikatos priežiūros paslaugų brangimas, finansavimo trūkumas, išteklių taupymo būtinumas, spartus pacientų norų ir poreikių augimas, nuolat stiprèjanti konkurencija verčia asmens sveikatos priežiūros įstaigų vadovus mąstyti, kaip mažiausiomis sąnaudomis išlikti konkurencingiems rinkoje, neprarasti gero įstaigos ịvaizdžio ir geriausiai patenkinti esamų bei potencialių vartotojų lūkesčius. Vienas iš būdų tai padaryti - ịvertinti, kaip efektyviai ịstaigose taikoma santykių rinkodara, kurios esmè - ilgalaikių santykių su vartotojais kūrimas ir palaikymas. Siekiant vartotojų lojalumo ir pranašumo, visi įstaigos darbuotojai turi puikiai išmanyti kokybines santykių dimensijas - pagrindinius santykių palaikymo ypatumus. Asmens sveikatos priežiūros įstaigų santykiai su vartotojais turi būti pagrịsti absoliučiai visų ịstaigos darbuotojų santykių rinkodaros dimensijų laikymusi, kas leistų juos kilstelèti ị kokybiškai aukštesnị lygmenį ir sustiprinti rinkos dalyvių asmens sveikatos priežiūros įstaigos ir vartotojo - tarpusavio ryšị. Abipusiai naudingų ilgalaikių santykių su vartotojais ir verslo klientais palaikymas turètų tapti 
prioritetu tụ ịstaigų, kurios siekia pelningai veikti konkurencinės rinkos sąlygomis, nes pastovus šių santykių tobulinimas suteikia įstaigoms konkurencinį pranašumą, kurị sunku nukopijuoti (Jurgelevičiūtè, Sūdžius, 2010, p. 118; Juščius, Navickas, 2009, p. 6; Juščius, Grigaitè, 2011, p. 71).

Santykių rinkodara ir jos pagrindinių dimensijų platus bei sėkmingas taikymas ịstaigose analizuojami daugelio Lietuvos ir užsienio mokslininkų darbuose, tačiau kiekvienas jų, atsižvelgdamas ị savo atliktų tyrimų kontekstą, apibūdina skirtingus tyrinëjimo objektus, išryškina skirtingus naujų verslo reiškinių aspektus. L. L. Berry (1995), Ph. Kotler, G. Armstrong, J. Saunder ir kt. (2003), A. Payne, D. Ballantyne ir M. Christopher (2005), A. J. Palmer (1996), D. Perpers, M. Rogers (1995) santykių rinkodarą nagrinèja kaip vartotojų pritraukimo ir išlaikymo priemonę. K. Das (2009), E. Gummesson (2007), Ch. Grönroos (2004), R. Žvirelienè, I. Bučiūnienè (2008) santykių rinkodaros koncepcijoje akcentuoja ne tik santykių tarp vartotojų ir ịstaigos užmezgimą bei palaikymą, bet ir abipusès sąveikos bei pažadų laikymąsi. J. A. Czepiel (1990), R. M. Morgan, S. D. Hunt (1994), J. N. Sheth, A. Parvatiyar (2002) išskiria tik tiekejo ir vartotojo santykius.

Tačiau minètuose tyrimuose neatsižvelgiama ị asmens sveikatos priežiūros ịstaigų ir pacientų santykių valdymo specifiką, todẻl kyla mokslinė problema, kokia santykių rinkodaros padètis Lietuvos asmens sveikatos priežiūros paslaugu rinkoje, kiek plačiai santykių rinkodaros metodai taikomi įstaigose, kokią realią naudą jie teikia ir kokių naujų galimybių ịstaigoms galètų teikti santykių rinkodaros dimensijų taikymas.

Tikslas: sudaryti santykių tarp vartotojų ir asmens sveikatos priežiūros įstaigų palaikymo teorini modelị, atskleidžiantį santykių rinkodaros ypatumų ištakų ir santykių rinkodaros dimensijų tarpusavio ryši bei formuojamą santykių rezultatą.

Objektas: santykių rinkodaros dimensijos.

Metodai: sisteminè mokslinès literatūros lyginamoji analizè ir sintezè, sugretinimas, detalizavimas, modeliavimas, priežastinių ryšiu nustatymas, loginė lyginamoji analizè ir sintezè.

\section{Santykių rinkodaros koncepcija apčiuopiamumo, sudėtingumo ir suprantamumo aspektais}

Santykių rinkodaros koncepcija pradèta tyrinèti nuo 1970 metų ir šiuo metu N. E. Coviello, R. J. Brodie ir kt. (1997, p. 510-511), V. Juščius, V. Navickas ir kt. (2006, p. 255), R. Žvirelienė (2005, p. 425-426) skiria šešias, jų manymu, svarbiausias tyrimo kryptis, veikusias santykių rinkodaros koncepcijos formavimąsi (žr. 1 lentelę). 
1 lentele. Santykių rinkodaros tyrimų krypčių charakteristikos

\begin{tabular}{|c|c|c|c|}
\hline \multirow{2}{*}{$\begin{array}{l}\text { Tyrimų } \\
\text { kryptys }\end{array}$} & \multicolumn{3}{|c|}{ Charakteristikos } \\
\hline & Požiūris į santykius & Rinkodaros tikslai & Sprendžiami uždaviniai \\
\hline $\begin{array}{l}\text { 1. Paslaugur } \\
\text { rinkodara }\end{array}$ & $\begin{array}{l}\text { Asmeniniai santykiai } \\
\text { su vartotojais, dalyvau- } \\
\text { jant paslaugu personalui } \\
\text { ir darant įtaką kitiems } \\
\text { rinkodaros veiksmams, } \\
\text { daug dėmesio skiriama } \\
\text { santykių gyvavimo ci- } \\
\text { klui }\end{array}$ & $\begin{array}{l}\text { Padidinti paslaugos teiki- } \\
\text { mo ir santykių su vartoto- } \\
\text { jais efektyvumą, valdant } \\
\text { suvokiamą siūlomos pa- } \\
\text { slaugos ir santykių ko- } \\
\text { kybę }\end{array}$ & $\begin{array}{l}\text { Vertès vartotojams tei- } \\
\text { kimas, didinant suvo- } \\
\text { kiamą kokybę, santykių } \\
\text { su vartotojais sukūrimas } \\
\text { ir plètojimas }\end{array}$ \\
\hline $\begin{array}{l}\text { 2. Tarporga- } \\
\text { nizaciniai } \\
\text { mainai }\end{array}$ & $\begin{array}{l}\text { Santykiai tarp vartotojų } \\
\text { ir pardavèjo, santykiai } \\
\text { tarp organizacijų }\end{array}$ & $\begin{array}{l}\text { Nustatyti efektyvius ir } \\
\text { naudingus santykius tarp } \\
\text { vartotojų ir pardavejo }\end{array}$ & $\begin{array}{l}\text { Vertès teikimas, san- } \\
\text { tykių tarp organizacijų } \\
\text { sukūrimas ir plètojimas }\end{array}$ \\
\hline $\begin{array}{l}\text { 3. Paskirstymo } \\
\text { kanalai }\end{array}$ & $\begin{array}{l}\text { Interorganizaciniai vers- } \\
\text { lo santykiai, nusakomi } \\
\text { ekonominiais mainais } \\
\text { ir galios naudojimu, } \\
\text { veikèjai tarpusavyje pri- } \\
\text { klausomi, būdinga atsa- } \\
\text { komoji reakcija }\end{array}$ & $\begin{array}{l}\text { Nustatyti efektyvias san- } \\
\text { tykines formas tarp pa- } \\
\text { skirstymo kanalo narių }\end{array}$ & $\begin{array}{l}\text { Efektyvių valdymo for- } \\
\text { mų kanalo santykiams } \\
\text { parinkimas, jègos ir } \\
\text { santykių efektyvumo } \\
\text { sąsaja, dominuojančios } \\
\text { ir priklausomos šalies } \\
\text { interesų suderinamumas }\end{array}$ \\
\hline 4. Tinklai & $\begin{array}{l}\text { Santykiai tinkle tarp } \\
\text { skirtingų įstaigų }\end{array}$ & $\begin{array}{l}\text { Nustatyti veiksnius, le- } \\
\text { miančius santykių tinklų } \\
\text { tarp veikejjų vystymąsi, } \\
\text { rinkų funkcionavimą ir } \\
\text { vystymąsi iš rinkos pers- } \\
\text { pektyvos }\end{array}$ & $\begin{array}{l}\text { Santykių sukūrimas ir } \\
\text { valdymas, santykių tin- } \\
\text { klų formavimasis, san- } \\
\text { tykių valdymo ir vietos } \\
\text { tinkle susikūrimo gali- } \\
\text { mybės }\end{array}$ \\
\hline $\begin{array}{l}\text { 5. Strateginis } \\
\text { valdymas }\end{array}$ & $\begin{array}{l}\text { Asmeniniai santykiai } \\
\text { su vartotojais, santykiai } \\
\text { tarp organizacijų, pa- } \\
\text { skirstymo kanalų ir tin- } \\
\text { klų valdymas }\end{array}$ & $\begin{array}{l}\text { Padidinti paslaugos teiki- } \\
\text { mo ir santykių su vartoto- } \\
\text { jais efektyvumą, valdant } \\
\text { suvokiamą siūlomos pa- } \\
\text { slaugos ir santykių ko- } \\
\text { kybę }\end{array}$ & $\begin{array}{l}\text { Vertès vartotojui teiki- } \\
\text { mas, lojalumo didini- } \\
\text { mas, vartotojų išlaiky- } \\
\text { mas, rinkodaros veiks- } \\
\text { mų ir vartotojų gyvavi- } \\
\text { mo ciklo suderinimas }\end{array}$ \\
\hline $\begin{array}{l}\text { 6. Informa- } \\
\text { cinès } \\
\text { technologijos }\end{array}$ & $\begin{array}{l}\text { Komunikacijomis ir as- } \\
\text { meniniu bendravimu pa- } \\
\text { laikomi dažnai tolimi ir } \\
\text { diskretūs organizaciniai } \\
\text { bei asmeniniai santykiai } \\
\text { su vartotojais }\end{array}$ & $\begin{array}{lr}\text { Padidinti } & \text { rinkodaros } \\
\text { efektyvumą } & \text { integruotų } \\
\text { rinkodaros } & \text { komunikacijų } \\
\text { priemonèmis } & \end{array}$ & $\begin{array}{l}\text { Vertès vartotojui teiki- } \\
\text { mas, lojalumo didini- } \\
\text { mas, vartotojų išlaiky- } \\
\text { mas, rinkodaros veiks- } \\
\text { mų ir vartotojų gyvavi- } \\
\text { mo ciklo suderinimas }\end{array}$ \\
\hline
\end{tabular}

Pirmoji kryptis nagrinejja rinkodarą paslaugų kontekste. Ji apima paslaugos personalo ir vartotojų asmeninius santykius, kurių esmé - didinti paslaugos teikimo ir santykių su klientais efektyvumą, valdant suvokiamą siūlomos paslaugos ir santykių kokybę. Antroji analizuoja tarporganizacinių mainų santykius. Ši kryp- 
tis apima ir santykių tarp pirkejo bei pardavejjo tyrimą, ir organizacinių santykių sandarą socialinių mainų teorijos kontekste. Trečioji tyrimų kryptis susijusi su santykių rinkodara, remiasi paskirstymo kanalų analize, kurioje pirmiausia akcentuojamos vertikalios rinkodaros sistemos, tačiau pastaruoju metu pereinama prie kontrolès būdų analizès ir efektyvių bei našių santykių kanaluose diegimo. Ketvirtoji tyrimų kryptis, susijusi su santykių rinkodara, tiria tinklo santykius, kuriuose pagrindinis dėmesys sutelkiamas ị gamybines rinkas ir daugelị ịstaigų siejančius ryšius. Penktoji kryptis kildinama iš strateginio valdymo problematikos ir remiasi šiuolaikine koncepcija, akcentuojančia santykių svarbą vertės kūrimo grandinėse. Šeštoji tyrimų kryptis remiasi informacinių technologijų diegimo aspektu ir tiria strategini poveikị, kurị informacinès technologijos daro santykiams organizacijų viduje ir tarp organizacijų.

Siekdami tiksliau išreikšti santykių rinkodaros koncepcijos esmę mokslininkai pateikia nemažai jos apibūdinimų, kuriuose akcentuojami skirtingi aspektai. Dažniausiai rinkodaros literatūroje cituojami santykių rinkodaros apibrèžimai pateikiami 2 lentelèje.

Apibendrindamas mokslininku pateiktas santykio rinkodaros koncepcijas, A. J. Palmer (1996, p. 19) pasiūlè santykio rinkodaros terminą interpretuoti trimis požiūriais: 1 . Taktiniu lygmeniu santykiu rinkodara apibūdinama kaip viena pagrindinių pardavimų rèmimo priemonių, pavyzdžiui, ịvairių lojalumo programų kūrimas pasitelkus modernias informacines technologijas. 2. Strateginiu lygmeniu santykių rinkodara suprantama kaip procesas, kai ịstaigos siekia „pririšti““ vartotoją teisiniais, ekonominiais, technologiniais, geografiniais ar laiko saitais. Šiuo atveju akcentuojamos pastangos išlaikyti esamus vartotojus, o ne pritraukti naujus. 3. Filosofiniu lygmeniu santykių rinkodara apibrež̌iama kaip rinkodaros esmès išraiška, nukreipianti rinkodaros strategiją nuo prekių ir jų gyvavimo ciklo ị vartotojų santykių gyvavimo ciklą. Pastaruoju atveju akcentuojamas tarpfunkcinis koordinavimas, apimantis orientacijos ị vartotoją veiksmų integravimą, visus organizacijos darbuotojus įtraukiant ị tikslinių rinkų poreikių tenkinimą.

S. Kušč (Кущ, 2003, с. 10), A. Dovalienè, R. Virvilaitė (2003, p. 100-101), R. Žvirelienè $(2005$, p. 425) skiria penkis požiūrius ị santykių rinkodarą: 1. Anglų ir australų požiūris, pabrėžiantis kokybès vadybos, paslaugų rinkodaros teorijų ir santykių su vartotojais ekonomikos reikšmę santykių rinkodarai. 2. Šiaurès mokyklos požiūris siejamas su gamybinès rinkodaros interaktyvaus tinklo teorija, paslaugų rinkodaros koncepcija ir santykių su vartotojais ekonomika. 3. Šiaurès Amerikos požiūris, akcentuojantis santykius tarp organizacijos ir vartotojo. 4. Tarptautinės rinkodaros ir pirkimo grupés požiūris nagrinejja tinklinị bendradarbiavimą pramonės organizacijų rinkoje. 5. Vokiečių požiūris pabrēžia gamybinès 
rinkodaros svarbą, santykių rinkodarą nagrinëjant tinklų, mainų ir neinstitucinės teorijų pagrindu.

2 lentelè. Santykiu rinkodaros sąvokos apibūdinimas moksliniu požiūriu

\begin{tabular}{|c|c|}
\hline Autorius & Santykiu rinkodaros sąvokos apibūdinimas \\
\hline Berry (1995, p. 236) & $\begin{array}{l}\text { Vartotojų pritraukimas, palaikymas ir santykių su jais } \\
\text { puoselèjimas }\end{array}$ \\
\hline Czepiel (1990, p. 13) & $\begin{array}{l}\text { Rinkos mainuose dalyvaujančių šalių tam tikrų specialių } \\
\text { santykių pripažinimas }\end{array}$ \\
\hline Das $(2009$, p. 326) & $\begin{array}{l}\text { Pelningų santykių su klientais ir suinteresuotomis pusemis } \\
\text { kūrimas, palaikymas ir puoselèjimas, užtikrinant numatytų } \\
\text { tikslų igyvendinimą }\end{array}$ \\
\hline Gummesson (2007, p. 133) & Santykiai, tinklai ir sąveika \\
\hline Grönroos $(2004$, p. 110) & $\begin{array}{l}\text { Santykių tarp vartotojų ir kitų interesantų kūrimas, } \\
\text { puoselejimas, stiprinimas ir, prireikus, nutraukimas, siekiant } \\
\text { pelno bei stengiantis pasiekti visų bendradarbiaujančių } \\
\text { pusių tikslus, šio proceso vykdymas ịsipareigojus abiem } \\
\text { pusėms }\end{array}$ \\
\hline $\begin{array}{l}\text { Kotler, Armstrong, Saunder } \\
\text { ir kt. }(2003 \text {, p. 411) }\end{array}$ & $\begin{array}{l}\text { Naudingu tarpusavio ryšiu su vartotojais, tiekejais ir } \\
\text { visuomene sukūrimas, palaikymas ir stiprinimas }\end{array}$ \\
\hline Morgan, Hunt (1994, p. 22) & $\begin{array}{l}\text { Rinkodaros veikla, nukreipta ị sėkmingą santykių sukūrimą, } \\
\text { puoselèjimą ir palaikymą }\end{array}$ \\
\hline $\begin{array}{l}\text { Payne, Ballantyne, } \\
\text { Christopher (2005, p. 862) }\end{array}$ & Vartotojų aptarnavimo, kokybės ir rinkodaros integracija \\
\hline Palmer (1996, p. 19) & $\begin{array}{l}\text { Pardavimų rèmimo priemonė, esamų vartotojų išlaikymas } \\
\text { ir ilgalaikių santykių kūrimas }\end{array}$ \\
\hline $\begin{array}{l}\text { Perpers, Rogers (1995, } \\
\text { p. 48) }\end{array}$ & $\begin{array}{l}\text { Klientų pritraukimas ir išlaikymas naudojant informacines } \\
\text { technologijas }\end{array}$ \\
\hline $\begin{array}{l}\text { Sheth, Parvatiyar (2002, } \\
\text { p. 4) }\end{array}$ & $\begin{array}{l}\text { Tiekėjų ir vartotojų santykiai, kuriuos galima paaiškinti } \\
\text { vadybos pokyčiais ir nauju rinkodaros mąstymu }\end{array}$ \\
\hline $\begin{array}{l}\text { Žvirelienè, } \quad \text { Bučiūnienè } \\
(2008, \text { p. 272) }\end{array}$ & $\begin{array}{l}\text { Nauja rinkodara, orientuota ị pagrindinị organizacijos tiks- } \\
\text { lą - vartotojų poreikių tenkinimą ir ilgalaikių santykių su } \\
\text { jais kūrimą }\end{array}$ \\
\hline
\end{tabular}

Mokslininkai iki šiol neturi vieningos nuomonès apie santykių rinkodarą, ją nagrinèja iš skirtingų pozicijų, tačiau kiekvieno jų nuomonè neprieštarauja kito nuomonei, jie papildo vienas kitą ir atskleidžia santykių rinkodaros, kaip naujos rinkodaros, koncepcijos esmę. M. H. Morris, J. Brunyee, M. Page (1998, p. 360) teigimu, santykių rinkodara ne tik skirtingiems mokslininkams, bet ir skirtingų organizacijų atstovams reiškia nevienodus dalykus. Dẻl santykių rinkodaros iggyvendinimo sąlygų specifiškumo nėra ir negali būti vienos bendros santykių rinkodaros teorijos (Juščius ir kt. 2006, p. 256). Pastebèta, kad ne tik nèra bendro sutarimo dèl 
santykiu rinkodaros sąvokos, bet dažnai vartojami ir šio termino sinonimai: naujas marketingas, squeikos požiūris, ryšiu marketingas. V. Juščiaus ir kt. (2006, p. 4) nuomone, nors susitarimas dèl santykiu rinkodaros apibūdinimo nepasiektas, šis terminas vis plačiau vartojamas ne tik mokslinèje literatūroje, bet ir verslo praktikoje.

\section{Santykių rinkodaros dimensijų raiškos teoriniai aspektai}

Santykių rinkodara yra procesas, kuris turi būti planuojamas, organizuojamas, o jo igyvendinimo eiga turi būti koordinuojama ir kontroliuojama. Pagrindinè šio proceso ịgyvendinimo priemonė yra santykių su privačiais ir verslo klientais valdymas, t. y. santykiu rinkodaros vertybiu ir strategijų, akcentuojant santykius su vartotojais, igyvendinimas praktikoje (Juščius, Navickas ir kt., 2009, p. 7). R. Žvirelienè, I. Bučiūnienè (2008, p. 274) apibendrino kitų mokslininkų darbus ir pastebėjo, kad daugelis jų pripažįsta, jog ịstaigos santykių, pagrịstų pasitikèjimu, ịsipareigojimu bei kitomis savybėmis, su vartotojais ir kitais rinkos dalyviais palaikymas bei stiprinimas sudaro santykių rinkodaros esmę.

Norint gerai išmanyti santykių su vartotojais valdymą, būtina teisingai taikyti pagrindinius santykių palaikymo principus. R. Žvirelienė, I. Bučiūnienè (2008, p. 274) akcentuoja, kad tik nedidelè dalis mokslinių tyrimų skirta svarbiausiems santykių rinkodaros principams operacionalizuoti. Be to, pabrèžiama, kad mokslininkai išskiria ir akcentuoja skirtingus santykių rinkodarai būdingus principus (3 lentelè sudaryta remiantis Žvireliene, Bučiūniene [2008, p. 275] ir papildyta autorių). Pastebèta, kad moksliniu požiūriu dominuoja dvi pagrindinès santykių rinkodaros dimensijos - pasitikejjimas ir ịsipareigojimas, kurias galima traktuoti kaip svarbiausias.

Pasitikèjimas - viena esminių sėkmingų santykių plètotės sąlygų. Jis apibrěžiamas kaip tikejjimas ar ịsitikinimas kitos šalies ketinimais santykiuose. Santykių rinkodaros kontekste pasitikėjimas reiškia verslo partnerystės aspektą, kuris nustato lygị, kuriuo kiekviena šalis jaučia, kad ji gali pasitiketi kitos šalies duoto pažado sąžiningumu (Yau, Mcfetridge, 2000, p. 1114). V. Navickas, A. Malakauskaitè $(2009$, p. 866) teigia, kad pasitikejjimo pagrindas - sąžiningumas ir patikimumas, nulemti ankstesnès pozityvios bendradarbiavimo patirties. R. M. Morgan, S. D. Hunt (1994, p. 22) pasitikèjimą apibrěžia kaip ,pasikliovimą mainų partnerio sąžiningumu“, o tai reiškia, kad visų pirma turi būti įsitikinimas, kad partneris vertas pasitikejjimo. Autorių nuomone, pasitikejjimas atsiranda iš nuoseklaus ir kompetentingo vartotojų aptarnavimo ir sąžiningo bei teisingo elgesio. Taigi ịstaiga, kuri nori išlaikyti esamus ir pritraukti naujus vartotojus, privalo didinti jų pasiti- 
kẻjimą tiek organizacija, tiek siūlomomis paslaugomis. Norint pasiekti šị tikslą, R. Žvirelienès, I. Bučiūnienès (2008, p. 276) tvirtinimu, organizacija privalo ịdiegti etišką sąžiningumu ir geromis verslo praktikomis pagrịstą požiūrị ị santykius tiek organizacijos darbuotojų tarpusavio santykiuose, tiek organizacijos santykiuose su tiekejais bei vartotojais. R. J. Lewicki, D. J. McAllister (1998, p. 438) pasitikejjimo terminą traktuoja kaip esminę sveikos asmenybès savybę, tarpasmeninių santykių pagrindą ir būtiną bendradarbiavimo sąlygą. L. Pilelienė analizavo kitų mokslininkų pasitikèjimo apibrèžimus ir atkreipe dèmesị ị O'Shaughnessy nuostatą, kad „pasitikejjimas yra esminis vartotojų lojalumo komponentas, pasireiškiantis vartotojų veiksmais, pagrịstais patiriamų kaštų ir gaunamų naudų skaičiavimu“ (Pilelienè, 2008, p. 113). Atsižvelgiant ị tai galima daryti prielaidą, kad kuo didesnis vartotojo pasitikejjimas ịstaiga, tuo stipresnis bus jo lojalumas.

K. Grayson, D. Johnson (2008, p. 242-243) skiria keturias pasitikejjimo rūšis: 1. Asmenybe paremtas pasitikejjimas - kyla vartotojo ir ịstaigos atstovams bendraujant. Priklauso nuo atstovo kompetencijų, žinių, mokẻjimo perduoti reikiamą informaciją vartotojui. 2. Procesu paremtas pasitikèjimas priklauso nuo to, kur bendraujama su organizacijos atstovais, kaip bendraujama, kokią informaciją gauna vartotojas. Vartotojo pasitikẻjimas auga kaupiant teigiamą informaciją apie organizaciją. Ji gaunama tiek iš pirminių šaltinių, pavyzdžiui, iš organizacijos atstovų, tiek iš antrinių, pavyzdžiui, prekès ženklo arba organizacijos reputacijos. 3. Sistema paremtas pasitikejjimas - tai vartotojų pasitikejjimas valdžia, t. y tikèjimas, kad valdžia palaikys pasisekimo tikimybę bet kurioje situacijoje ir suteiks garantijų. 4. Bendras pasitikejjimas - dažniausiai paremtas ịstaigos reputacija, prekès ženklo žinomumu ir t. t. R. Žvirelienè, I. Bučiūnienė (2008, p. 276) skiria tris skirtingus vartotojų pasitikejjimo lygius:

- Vartotojai, kuriems būdingas išskaičiavimu paremtas pasitikèjimas: pasikliauja paslaugų teikèju, nes tiki, kad tiekejjas suinteresuotas neprarasti reputacijos ir pelno, kuriuos patirtų, jei būtų sugriautas pasitikèjimas.

- Vartotojai, kuriems būdingas žiniomis paremtas pasitikejjimas: stengiasi geriau pažinti įmonę, numatyti tolesnius jos veiksmus. Čia svarbi efektyvi dvipusè komunikacija, todèl vartotojai turi geranoriškai dalintis informacija su ịstaiga, o ịstaiga - geranoriškai domètis vartotojų poreikiais ir problemomis bei atitinkamai reaguoti.

- Vartotojai, kuriems būdingas identifikacija paremtas pasitikejjimas: pasitiki ịstaiga ir tiki, kad ji veiks paisydama jų interesų. Paslaugų teikejjas ir prekès tiekejas puikiai išmano vartotojų poreikius bei pageidavimus, o vartotojai suvokia, kad jų pageidavimai išpildomi. 
Deimena Kiyak, Arina Medvedeva

3 lentelè. Santykių rinkodaros dimensijų ịvairovè moksliniu požiūriu

\begin{tabular}{|c|c|c|c|c|c|c|c|c|c|c|c|}
\hline Autoriai & 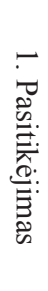 & 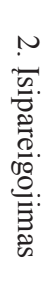 & 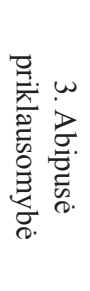 & 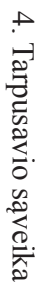 & 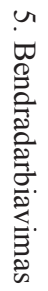 & $\begin{array}{l}\stackrel{a}{\Omega} \\
\stackrel{0}{0} .\end{array}$ & 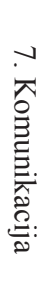 & 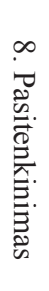 & $\begin{array}{l}0 \\
\widehat{0} \\
\frac{1}{\sigma}\end{array}$ & 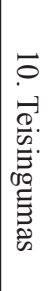 & 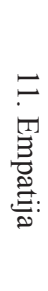 \\
\hline Dweyr ir kt. (1987)* & $\bullet$ & $\cdot$ & & & & & & & & & \\
\hline Anderson, Weitz (1989)* & - & & • & & • & & • & & • & & \\
\hline Anderson, Narus (1990)* & $\cdot$ & & $\bullet$ & & $\bullet$ & $\cdot$ & $\cdot$ & & & & \\
\hline Morgan, Hunt (1994)* & $\bullet$ & • & & & & & $\cdot$ & • & & & \\
\hline Wilson $(1995)^{*}$ & & $\bullet$ & $\bullet$ & & & & & & $\cdot$ & & \\
\hline Styles, Ambler (1996)* & • & $\cdot$ & $\bullet$ & • & & & & & & & \\
\hline Fontenot, Wilson (1997)* & $\bullet$ & $\cdot$ & $\bullet$ & $\cdot$ & $\bullet$ & $\bullet$ & & & & & \\
\hline Butile, Ahmad (1999)* & $\bullet$ & $\bullet$ & & $\bullet$ & & & & & $\cdot$ & & \\
\hline Garbarino, Johnson (1999)* & $\bullet$ & $\bullet$ & & & & & & $\cdot$ & & & \\
\hline Teale $(1999)^{*}$ & $\cdot$ & $\cdot$ & & $\cdot$ & & $\cdot$ & & & & $\cdot$ & \\
\hline Palmer $(2000)^{*}$ & $\bullet$ & $\cdot$ & $\bullet$ & $\bullet$ & $\bullet$ & & & & & & \\
\hline Perry ir kt. (2001)* & $\bullet$ & $\cdot$ & $\bullet$ & $\cdot$ & & & & & & • & \\
\hline Yau ir kt. (2000) & $\cdot$ & $\cdot$ & $\cdot$ & & & & & & & & $\cdot$ \\
\hline Navickas, Malakauskaitè (2009) & $\cdot$ & $\cdot$ & & • & & & & & • & & \\
\hline Jucaitytė, Maščinskienė (2011) & $\cdot$ & $\cdot$ & & & & & & • & & & \\
\hline Jurgilevičiūtè, Sūdžius (2010) & $\cdot$ & $\bullet$ & & & & & & & $\cdot$ & & $\cdot$ \\
\hline Žvirblienè, Bučiūnienè (2008) & $\cdot$ & $\cdot$ & $\cdot$ & $\cdot$ & $\bullet$ & $\cdot$ & $\bullet$ & $\cdot$ & $\cdot$ & $\cdot$ & $\cdot$ \\
\hline Pilelienè (2008) & $\bullet$ & $\bullet$ & & & & & & $\cdot$ & $\bullet$ & & \\
\hline Juščius, Grigaitė (2009) & $\bullet$ & $\cdot$ & & & $\bullet$ & $\cdot$ & $\bullet$ & $\cdot$ & $\bullet$ & & \\
\hline $\begin{array}{l}\text { Bivainis, Daukševičiūtè, Vilkaitè } \\
(2011)\end{array}$ & & & & • & • & & • & & • & & • \\
\hline Androšiūnaitè, Melnikas (2013) & • & • & • & • & • & • & • & • & • & & \\
\hline
\end{tabular}

* Šaltinis: Žvirelienè ir kt. (2008, p. 275).

Pasitikèjimas įtvirtinamas dokumentais kaip mainų santykiai ir dažnai laikomas svarbiausia verslo santykių sudedamaja dalimi bei pripažintas kaip pagrindinis struktūrinis elementas santykių rinkodaros modeliavimo procese (Yau, Mcfetridge ir kt., 2000, p. 1114; Anderson, Narus, 1991, p. 98; Morgan, Hunt, 1994, p. 28).

Is sipareigojimas. Apibrèžiamas kaip verslo partnerystės aspektas, kuris vartotojui ir tiekėjui pasireiškia vieningu veikimu, siekiant užsibrèžto tikslo (Sweidan, Al-Dmour ir kt., 2012, p. 157; Yau ir kt., 2000, p. 1113). Anot V. Juščiaus ir kt.: „Isipareigojimas reiškia ilgalaikị siekimą išlaikyti vertingą ryšį, tikintis, kad tai ly- 
giaverčiai mainai“ (2006, p. 257). D. Bejou (2005, p. 44) teigimu, įsipareigojimas pasireiškia, kai abi šalys yra lojalios viena kitai, kai jos suvokia, kad tarpusavio santykiai suteiks ne tik naudą, bet ir pasitenkinimą. „Isipareigojimas neabejotinai susijęs su pasitikejjimo idejja, tačiau neaišku, ar kuris nors turi atsirasti pirmiau. Nèra aišku, ar ịsipareigojimas yra augančio pasitikejjimo rezultatas, ar pasitikèjimas kyla iš sprendimo ịsipareigoti. İsipareigojimas taip pat gali būti neigiamai susijęs su didesne konkurencija ir alternatyvių santykių partnerių egzistavimu“ (Žvirelienè ir kt., 2008, p. 275).

Tarpasmeniniuose santykiuose, kurie susiklostę tarp pirkèjo ir pardavèjo, įsipareigojimą galima apibūdinti kaip dinamišką procesą, kuris progresuoja laikui bėgant (Cann, 1998, p. 399). İsipareigojimo procesas prasideda nuo elementaraus pardavejo poreikio surasti pirkejją savo produkcijai ir nuo pirkejjo noro įsigyti prekę, kuri patenkintų jo poreikius. Šalims būdingos ịvairios ịsipareigojimo formos, rodančios skirtingus santykių lygius. İsipareigojimas padeda veiksmingai kontroliuoti socialinį ir verslo elgesį visuomenèje, išsklaido abejones, sukuria pasitikèjimą ir padeda užmegzti glaudžius ryšius (Chattananon ir kt., 2009, p. 257). Issipareigojimo aspektą, koks egzistuoja santykių rinkodaroje, sudaro vartotojo ir lojalumo prekès ženklui vystymasis bei tobulejimas, be to, kaip nurode Th. Levitt (1983, p. 87), ilgalaikiai santykiai su pardavejju. Taigi ilgalaikiams santykiams, kad jie galètų egzistuoti, būtinas ịsipareigojimas. Gerokai pažengusioje santykių stadijoje ịsipareigojimas yra toks tvirtas, kad jo praktiškai neįmanoma sugriauti (Cann, 1998, p. 399).

Skiriami šie svarbiausi veiksniai, turintys įtakos pasitikèjimo ir ịsipareigojimų santykiams (Žvirelienè, 2008, p. 275): santykių nutraukimo sąnaudos, santykių teikiama nauda, bendros vertybès (bendri partneriu ịsitikinimai apie konkrečioje situacijose svarbius, prideramus ir tinkamus elgesio bruožus, tikslus bei politikas), komunikacija, oportunistinè elgsena.

Abipusiškumas (abipusė priklausomybė) yra verslo partnerystės aspektas, kuris leidžia vienai šaliai suteikti naudą ar padaryti nuolaidų kitai, vėliau kita šalis atsako tuo pačiu (Olotu ir kt., 2010, p. 50; Yau ir kt., 2000, p. 1113). Anot L. Y. M. Sin, A. C. B. Tse ir kt. (2002, p. 661), abipusiškumas - tai supratimas apie dvišalius nenumatytus atvejus, abipusiai naudingą tarpusavio priklausomybę ir vertybių, kuriomis šalys keičiasi, kokybę. M. Damkuvienė, R. Virvilaitė (2007, p. 320) konstatuoja, kad dauguma autorių apibrèžia abipusę priklausomybę kaip aktyvų abiejų šalių dalyvavimą kuriant vertę ir teigia, kad vartotojas gauna didelę naudą, kai artimiau bendradarbiauja su organizacija, o organizacija, bendraudama su vartotojais, pasiekia didesnị konkurencini pranašumą. Visi santykių dalyviai priklauso vienas nuo kito, t. y. gauna abipusę naudą. Vartotojas yra priklauso- 
mas nuo teikèjo siūlomų paslaugų, o teikèjo verslo sėkmė priklauso nuo vartotojo sprendimo pirkti ar ne jo paslaugas. A. Chattananon, J. Trimetsoontorn (2009, p. 257) atskleidžia ryšius tarp abipusiškumo ir empatijos bei santykių rinkodaros ir mainų. Abipusiškumas ir įsipareigojimas yra taip susiję, kad abipusis susitarimas parodo bendradarbiavimą.

Tarpusavio sąveika. M. Damkuvienès, R. Virvilaitės nuomone, „santykių raida priklauso nuo sąveikos dažnumo, kadangi nuolat pasikartojanti sąveika tarp dvejų rinkos dalyvių sąlygoja ryšius, kurie yra būtini santykiams tarp jų“ (2007, p. 320). Apibendrinant galima teigti, kad santykiai tarp vartotojo ir ịstaigos formuojasi periodiškai bendradarbiaujant. Iš to galima daryti prielaidą, kad kuo dažniau rinkos dalyviai efektyviai bendrauja tarpusavyje, tuo stipresni yra jų santykiai.

Bendradarbiavimas - tai siekis darniai ir koordinuotai dirbti, pasiruošimas padèti arba paremti savo partnerị. R. Žvirelienès ir kt. (2008, p. 277) nuomone, bendradarbiavimas - tai mokymosi pagrindas. Santykius palaikančių šalių pagrindas - atvirumas, abipusiškumas, parama ir pripažinimas - yra pagrindiniai mokymosi proceso elementai. Taigi bendradarbiavimas teikia galimybių greitai išspręsti problemas, gauti ir perduoti žinias, kitaip tariant, tai leidžia suinteresuotoms šalims tobulèti ir stiprinti tarpusavio santykius. L. Jurgilevičiūtè, V. Sūdžius (2010, p. 121) teigia, kad vartotojai, su kuriais nuolat bendradarbiaujama, labiau linkę palaikyti santykius su paslaugų teikèju. Bendradarbiavimo efektyvumą lemia kultūra ir kompetencija, taip pat tam tikra individuali paslauga ar finansinè priemonè.

Galia. Anot S. Staniulienès, galia - tai „dviejų ar daugiau žmonių tarpusavio santykių aspektas, [...] sugebėjimas priversti kokị nors asmenị ką nors daryti“ (2008, p. 122). Svarbiausias galios aspektas - priklausomybè. Kuo didesnè vartotojo priklausomybè nuo teikejjo, tuo didesnè teikèjo galia tarpusavio santykiuose. Kuo daugiau vartotojas yra priklausomas nuo organizacijos paslaugų, tuo lengviau organizacijai ịtikinti ji pirkti jos produktus ar paslaugas.

Komunikacija yra sėkmingo rinkos dalyvių bendradarbiavimo sąlyga. V. Juščiaus ir kt. (2006, p. 100) nuomone, komunikaciją galima apibūdinti kaip oficialų ir neoficialų pasidalinimą informacija tarp vartotojo ir paslaugos tiekejjo. R. Žvirelienè ir kt. (2008, p. 277) pabrèžia, kad sąmoningas ar nesąmoningas netinkamas informacijos pateikimas organizacijos darbuotojams ir verslo partneriams gali sukurti terpę nesusipratimams ir konfliktams atsirasti, t. y. sukelti grèsmę vidiniams organizacijos santykiams. O netiksli informacija, pateikta išorejje - vartotojams ir kitiems verslo partneriams, gali sugriauti jų pasitikẻjimą organizacija. J. C. Anderson, J. A. Narus (1991, p. 108) pažymi, kad komunikacija yra stiprus pasitenkinimą lemiantis veiksnys ir jeigu vartotojas organizacija pasitiki, šiai daug geriau pavyksta patenkinti vartotojo poreikius, o tai yra vienas svarbiausių žings- 
nių formuojant ilgalaikius santykius. R. Žvirelienès ir kt. (2008, p. 277) nuomone, komunikacija yra svarbi santykių rinkodaros dimensija, nes prasminga ir laiku vykstanti verslo partnerių komunikacija stiprina pasitikejjimą, to išdava - glaudūs santykiai, paremti abipusiu ịsipareigojimu, pasitenkinimu ir bendradarbiavimu.

Pasitenkinimas - tai emocinè būsena, pasiekiama, išpildžius vartotojo norus ir lūkesčius. Anot T. Palaimos, V. Auruškevičienès (2006, p. 105), pasitenkinimas - tai dimensija, kuri labiausiai veikia vartotojų lojalumą ir šnekas. Pasitenkinimas - tai vartotojo emocinis paslaugos įvertinimas, pagrịstas jo asmenine patirtimi per tam tikrą laikotarpị. R. Žvirelienè ir kt. (2008, p. 276), analizuodami kitų autorių publikacijas, atkreipia dėmesị ị tai, kad pasitenkinimas yra pagrindinis santykių tęstinumą lemiantis veiksnys, kurio dèka tarp santykius palaikančiu rinkos dalyvių atsiranda aukštesnio lygio ịsipareigojimas, ir santykių nutraukimas tampa vis sudètingesnis. Kitaip tariant, kuo didesni pasitenkinimą paslaugomis jaučia vartotojas, tuo didesnis jo noras palaikyti partnerystės santykius su įmone. Pasitenkinimas gali būti ugdomas ne tik per asmeninę patirtį, bet ir remiantis kitų žmonių nuomone bei patirtimi. Jis daugiausiai priklauso nuo santykių trukmès, todèl laukiamas pasitenkinimo lygis turi įtakos pasitikèjimo trukmei. Pasitenkinimas - tai dimensija, stiprinanti pasitikẻjimą tarp santykius palaikančių šalių, kuria galima įvertinti, kiek santykius palaikantys rinkos dalyviai patenkinti vienas kito veikla. Tai prognozuoja pasitikèjimą ir lemia santykių tęstinumą.

Vertè. Organizacijoms labai svarbu suprasti kaip vartotojas suvokia vertę, nes tai padeda išsiaiškinti jo tikslus ir reikalavimus. R. Vaitkienès, V. Pilibaitytès (2008, p. 46) požiūriu, vertès sąvoka mokslinejje literatūroje ir praktineje veikloje vartojama ịvairiomis prasmėmis, tačiau pastaruoju metu rinkodaros literatūroje dominuoja dvi vertès sampratos - vertė vartotojui ir vartotojo vertè organizacijai. Būtent vertè vartotojui yra prielaida visoms kitoms vertėms, todèl ją galima vadinti visų rinkodaros sprendimų pagrindu, nes didesnès vertės vartotojui teikimas laikytinas vienu svarbiausių konkurencinį pranašumą didinančių bei vartotojo lojalumą užtikrinančių veiksnių. L. Jurgilevičiūte, V. Sūdžius (2010, p. 121) ir D. Kiyak (2013, p. 89) vartotojo suvokiamą vertę apibūdina kaip santykị tarp gautos naudos ir patirtų sąnaudų. Gauta nauda apima paslaugą ir su ja susijusi papildomą pasitenkinimą, kuriuos vartotojas gauna iš paslaugų teikejjo, o patirtos sąnaudos - tai ìvairios sąnaudos, kurių gali turèti vartotojas vertindamas, ịsigydamas, naudodamas duotajį rinkos pasiūlymą bei jo atsikratydamas (pvz., socialinès, ekonominès, psichologinès ir pan.). Anot D. Kiyak, „tradiciškai vertė vartotojui siejama su iš pagrindinio produkto gaunamos apčiuopiamos ir neapčiuopiamos naudos bei vartotojo patiriamų piniginių bei nepiniginių sąnaudų, ịsigyjant produktą, santykiu“ (2013, p. 89). 
Vartotojui suteikta vertė - tai santykis tarp planuotų arba neplanuotu piniginių išlaidų, laiko, kurị skyrė vartotojas prekès arba paslaugos pirkimui, energinių ir moralinių sąnaudų bei prekès, paslaugų, personalo ir įmonės įvaizdžio vertės. R. Žvirelienè ir kt. (2008, p. 277) pabrěžia, kad ilgalaikè, tęsiamų santykių tarp organizacijos ir jos verslo partnerių vertė sukuriama bendradarbiaujant.

Teisingumas. Šis principas - socialinio stabilumo ir žmogiškumo pagrindas. P. E. Murphy, G. R. Laczniak, G. Wood (2007, p. 49) ịsitikinę, jeigu tarp vartotojo ir paslaugos teikèjo santykiai yra nesąžiningi vienas kito atžvilgiu, nesilaikoma teisingumo ir padorumo principų, mažai tikètina, kad jie ilgai tęsis. Kiekvienas asmuo gyvena visuomenėje, todèl turi pripažinti ne tik savo, bet ir kito asmens interesus bei naudą. Visi rinkos dalyviai privalo būti sąžiningi, atsakingi ir teisingi vienas kito atžvilgiu, priešingu atveju jie neturès galimybès palaikyti visaverčius tarpusavio santykius.

Empatija - tai verslo partnerystės aspektas, kuris leidžia šalims matyti situaciją iš kitos šalies perspektyvos. Ji apibrěžiama kaip siekis suprasti kito troškimus ir tikslus. Empatija reiškia galimybę atskiroms šalims pamatyti situaciją iš kitos šalies perspektyvos vadovaujantis tikru pažinimo jausmu (Williams, 2012, p. 12; Yau ir kt., 2000, p. 1113). Anot R. Žvirelienès, I. Bučiūnienès (2008, p. 277), empatija - svarbi santykių rinkodaros dimensija, kuri suprantama kaip organizacijos ir vartotojo bei kitų suinteresuotų šalių bendravimo aspektas, o ne valdomas parametras, ji leidžia abiem šalims pažvelgti ị situaciją viena iš kitos perspektyvos. Kitaip tariant, empatija - sugebejjimas įsijausti ir ịgyvendinti tai, ką jaučia kitas žmogus. Ji prasideda kito žmogaus emocinès būsenos identifikavimu, vèliau išgyvenamas jausmas, kuris tuo momentu yra apėmęs kitą asmenị ir atpažintas ir išgyvenamas jausmas vèl išreiškiamas ịvairiomis formomis ir būdais. Apibendrinant empatija - tai kito žmogaus motyvų, su kuriais mes galime nesutikti, supratimas. Užsienio mokslininkų tyrimai rodo, kad empatija yra būtina sąlyga, puoselëjant teigiamus santykius tarp verslo partnerių.

Visos pateiktos santykių rinkodaros dimensijos yra tarpusavyje susijusios ir viena kitai daro ịtaką (1 pav.). Šių dimensijų raiška kartu su formaliomis ịstaigos priemonėmis, tokiomis kaip ịstaigos darbuotojų elgesio taisyklès ir etikos kodeksas, stiprina santykius ir skatina juos puoselèti. 


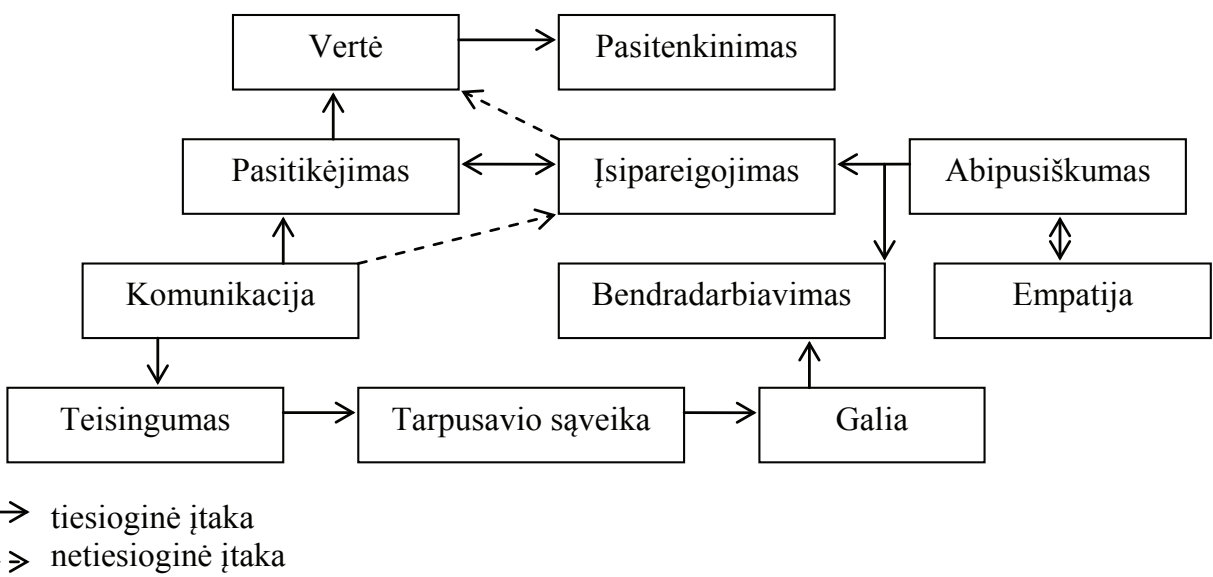

1 pav. Santykių rinkodaros dimensijų tarpusavio sąveika Šaltinis: sudaryta autorių

\section{Santykių rinkodaros dimensijų įtaka vartotojų lojalumui}

Santykių rinkodaros tyrejjai akcentuoja skirtingus vartotojo lojalumo ir santykių rinkodaros sąsajų aspektus. J. Bivainio, I. Daukševičiūtės ir N. Vilkaitės (2011, p. 351-352) nuomone, mokslineje literatūroje skiriami trys skirtingi požiūriai: 1. Vartotojų lojalumas - centrinè santykių rinkodaros koncepcija. 2. Vartotojų lojalumas - pagrindinis santykių rinkodaros tikslas. 3. Vartotojų lojalumas - santykių rinkodaros pasekmè / rezultatas.

Tyrimai, kuriuose analizuojamas vartotojų lojalumas, kaip santykių rinkodaros rezultatas, suskaidyti ị dvi pagrindines grupes (Pilelienè, 2008, p. 111; Henning-Thurau ir kt., 2002, p. 233):

1. Pirmosios grupés tyrimuose akcentuojama vienos santykių rinkodaros dimensijos įtaka vartotojų lojalumui. Jie atskleidžia vienadimensị požiūrį. Šio požiūrio veiksnių itaka vartotojų lojalumui pateikta 4 lentelëje.

2. Antroji tyrimų grupé analizuoja dviejų ar daugiau santykių rinkodaros dimensijų visumą ir šių dimensijų ar jų kombinacijų įtaką vartotojų lojalumui, todèl šiuose tyrimuose tiriamas ne tik ryšys tarp veiksnio bei rezultato, bet ir ryšiai tarp paskirų veiksnių. Toks požiūris vadinamas daugiadimensiu. 
Deimena Kiyak, Arina Medvedeva

4 lentele. Vienadimensio požiūrio veiksnių ịtaka vartotojų lojalumui

\begin{tabular}{|c|c|c|}
\hline Požiūrio veiksnys & $\begin{array}{c}\text { Dimensijos } \\
\text { ittaka vartotojų } \\
\text { lojalumui }\end{array}$ & Komentaras \\
\hline Pasitikèjimas & Tiesioginè & $\begin{array}{l}\text { Kuo didesnis vartotojų pasitikejjimas įstaiga, tuo } \\
\text { didesnis jų lojalumas }\end{array}$ \\
\hline İsipareigojimas & Tiesioginè & $\begin{array}{l}\text { Kuo didesnis vartotojų ịsipareigojimas ịstaigai, } \\
\text { tuo ilgiau egzistuoja jų tarpusavio santykiai }\end{array}$ \\
\hline Abipusiškumas & Turi ịtakos & $\begin{array}{l}\text { Kuo didesnę naudą įstaiga gali suteikti } \\
\text { vartotojams, tuo didesnè tikimybè, kad jie taps } \\
\text { lojalūs }\end{array}$ \\
\hline Tarpusavio sąveika & $\begin{array}{l}\text { Neturi } \\
\text { tiesioginès įtakos }\end{array}$ & $\begin{array}{l}\text { Vartotojai dèl ịvairių priežasčių (pavyzdžiui, } \\
\text { dėl alternatyvos nebuvimo) gali būti priversti } \\
\text { dažnai bendrauti su įstaigos darbuotojais, tačiau } \\
\text { nebūti jai lojalūs }\end{array}$ \\
\hline Bendradarbiavimas & Turi įtakos & $\begin{array}{l}\text { Vartotojai, su kuriais nuolat bendradarbiaujama, } \\
\text { rodo didesni susidomèjimą palaikyti ilgalaikius } \\
\text { santykius su įstaiga }\end{array}$ \\
\hline Galia & $\begin{array}{l}\text { Neturi } \\
\text { tiesioginès įtakos }\end{array}$ & $\begin{array}{l}\text { Vartotojai gali būti priklausomi nuo ịstaigoje } \\
\text { teikiamų paslaugų, tačiau nebūti jai lojalūs }\end{array}$ \\
\hline Komunikacija & Turi ịtakos & $\begin{array}{l}\text { Prasminga komunikacija tarp rinkos dalyvių, } \\
\text { vykstanti laiku, didina vartotojų pasitikèjimą } \\
\text { instaiga, o kuo didesnis pasitikėjimas, tuo } \\
\text { didesnis lojalumas }\end{array}$ \\
\hline Pasitenkinimas & Tiesioginè & $\begin{array}{l}\text { Kuo labiau vartotojai patenkinti ịstaigos } \\
\text { teikiamomis paslaugomis, tuo didesnè } \\
\text { tikimybè, kad jie bus jai lojalūs }\end{array}$ \\
\hline Vertè & Turi įtakos & $\begin{array}{l}\text { Kuo didesnę vertę įstaiga gali suteikti } \\
\text { vartotojams, tuo didesnè tikimybė, kad jie taps } \\
\text { lojalūs }\end{array}$ \\
\hline Teisingumas & Turi įtakos & $\begin{array}{l}\text { Jeigu tarp vartotojų ir įstaigos nesilaikoma } \\
\text { teisingumo ir padorumo principų, mažai } \\
\text { tikètina, kad tokie santykiai bus ilgalaikiai }\end{array}$ \\
\hline Empatija & Turi įtakos & $\begin{array}{l}\text { Būtina sąlyga puoselèjant teigiamus ir } \\
\text { ilgalaikius santykius tarp vartotojų ir ịstaigos }\end{array}$ \\
\hline
\end{tabular}

Tiesiogiai vartotojų lojalumą veikia pasitikèjimas, įsipareigojimas ir pasitenkinimas, tuo tarpu tarpusavio sąveika ir galia neturi jam tiesioginès įtakos. Kiekvienas iš minètų veiksnių ir jų daroma ịtaka vartotojų lojalumui analizuojami atskirai, tačiau tikètina, kad šie veiksniai pasireiškia kartu. 
Santykiụ rinkoda ros ypatumụ ištakos

- Pasitikejimas ịstaiga ir čia dirbančais darbuotojais

- Konfidencialumas, patikimumas, gera reputacija, žinomumas

- Kompetentingumas, etiškumas, būtinos informacijos suteikimas

- Kaip varto tojas pradejo naudoti ịstaigos paslaugomis

Santykiu rinkodaros

dimensijos

Santykiu

rezultatas

- Vartotojo ir ịstaigos darbuotojụ santykių naudingumas

- Vartotojo požiūis ị paslaugụ kokybẹ, aptarnavimo greitị

- Vartotojo ypatingụ poreikių supratimas

- Mokamu paslaugu kaina

- Vartotojụ ir ịstaigos darbuotojụ etiškas ir mandagus

- Vartotojo apsilankymo ịstaigoje dažnumas

- İstaigos darbuotojụ pasirušmas skirti pakankamai laiko vartotojui

- İstaigos darbuotojụ pasiruošimas atsakyti ị vartotojo klausimui

- Atsakingumas reaguojant i pacientu musiskundimus

- Vartotojo priklausomybé nuo ịstaigoje teikiamu paslaugy

- Galimybè vartotojui bendrauti su ịstaigos darbuotojais jam patogiu būdu, laiku ir greitai gauti atsakymus ị jam rūpimus klausimus

- Paslaugú kokybè, aptarnavimo greitis, aplinka, darbo laikas, paslaugu kainos

- Vartotojui malonus bendravimas su ịstaigos

darbuotojais

- Diagnostikos ịranga ir naudojamos gydymo priemonès

- Geri vartotojo santykiai su ịstaig os darbuotojais

- Paslaugy kokybe ir aptarnavimo greitis, skiriamas gydymas

- Sąüningumas, atsakingumas, teisingumo principụ $\rightarrow$ Teisingumas laikymasis

- Vartotojo emocinès būsenos supratimas ir pastangos jam padeti

Empatija

Isipareigojimas

Bendradarbiavimas

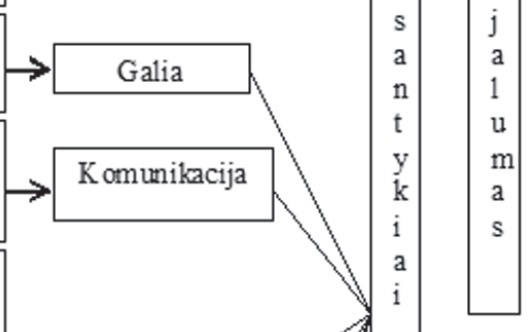

2 pav. Santykių tarp vartotojų ir asmens sveikatos priežiūros ịstaigų palaikymo modelis

Šaltinis: sudaryta autorių 


\section{Santykių tarp vartotojų ir asmens sveikatos priežiūros įstaigụ palaikymo teorinis modelis}

Atlikus santykių rinkodaros konceptualių požiūrių analizę ir atskleidus santykių rinkodaros dimensijų ịvairovę bei jų tarpusavio sąveiką konstatuotina, kad santykių rinkodaros ypatumų teisingo taikymo rezultatas - ilgalaikiai vartotojų ir įstaigos santykiai, kurių pasekmè - vartotojų lojalumas. Sudarytas santykių tarp vartotojų ir asmens sveikatos priežiūros ịstaigu palaikymo teorinis modelis (2 pav.).

Pateiktame modelyje matyti, kad yra daugybè veiksnių, galinčiu turèti įtakos santykių rinkodaros principų formavimuisi asmens sveikatos priežiūros įstaigoje. Be to, laikomasi nuomonès, kad visi santykių rinkodaros ypatumai turi ịtakos tiek ilgalaikių santykių vartotojų ir asmens sveikatos priežiūros ịstaigos formavimuisi, tiek vartotojų lojalumui.

\section{Išvados}

1. Santykių rinkodaros koncepcija vystèsi veikiama savarankiškų, skirtingomis kryptimis vykdytų mokslinių tyrimų, todèl konsensuso tarp mokslininkų dèl santykių rinkodaros apibrèžimo nepasiekta. Mokslininkai santykių rinkodarą apibrèžia iš skirtingu pozicijų: vieni nagrinejja, kaip vartotojų pritraukimo ir išlaikymo priemonę, kiti akcentuoja ne tik santykių užmezgimą ir palaikymą, bet ir abipusės sąveikos bei pažadų laikymąsi, dar kiti nurodo tik tiekejo ir vartotojo santykius. Santykių rinkodarą galima apibrež̌ti kaip naujų vartotojų pritraukimą, santykių tarp jų ir įstaigos kūrimą, puoselejimą, stiprinimą ir, prireikus, nutraukimą, siekiant vartotojų ir įstaigos tikslų.

2. Atskleistos šios pagrindinès santykių rinkodaros dimensijos: pasitikèjimas, įsipareigojimas, abipusė priklausomybè, tarpusavio sąveika, bendradarbiavimas, galia, komunikacija, pasitenkinimas, vertè, teisingumas ir empatija. Pasitikejjimas ir ịsipareigojimas - esminès santykių rinkodaros dimensijos, parodančios santykių tarp ịstaigos ir vartotojų lygị bei svarbą, tačiau nekonkretizuota, ar ịsipareigojimas yra augančio pasitikejjimo rezultatas, ar pasitikèjimą lemia sprendimas įsipareigoti. Vertè siejama su pasitikèjimu iš vartotojo pusès. Jei patenkinami vartotojo norai ir poreikiai, vartotojo suvokiama vertè lemia pasitenkinimą. Abipusè priklausomybė ir įsipareigojimas siejami su abipusiu susitarimu, kuriam turi ịtakos empatija, ir rodo abiejų šalių bendradarbiavimą. Paslaugų įstaigos ir vartotojai sąveikauja bendradarbiaudami, tai yra kuo dažniau jie bendrauja tarpusavyje laikyda- 
miesi teisingumo principų, tuo tvirtesni jų santykiai ir tuo daugiau galios turi vienas rinkos dalyvis skatinant kitą priimti jam tinkamą sprendimą. Komunikacija tiesiogiai veikia pasitikejjimą ir netiesiogiai - isipareigojimą. Dalijimasis aktualia ir laiku gaunama informacija sustiprina abu šiuos elementus.

3. Sudarytame vartotojų ir asmens sveikatos priežiūros ịstaigų santykių palaikymo teoriniame modelyje konstatuojama, kad tiesioginę ịtaką vartotojų lojalumui asmens sveikatos priežiūros rinkoje turi pasitikèjimas, įsipareigojimas ir pasitenkinimas. Santykių rinkodaros principai - tarpusavio sąveika ir galia - asmens sveikatos priežiūros rinkoje tik iš dalies lemia vartotojų lojalumą.

Gauta 20150210

Pasirašyta spaudai 20150317

\section{Literatūra}

Anderson, J. C., Narus, J. A. (1991). Partnering as a Focused Market Strategy. California Management Review, No. 1: 95-113.

Androšiūnaitè, A., Melnikas, B. (2013). Santykių rinkodara teisinių paslaugų rinkodaros strategijoje. Verslas XXI amžiuje, Nr. 5 (1): 59-63.

Bejoy, D. (2005). Treating students like customers. Business ethics, Vol. 4, No. 3: 44-47.

Berry, L. L. (1995). Relationship marketing of services - growing interest, emerging perspectives. Journal of the Academy of Marketing Science, Vol. 23, No. 4: 236-245 [interaktyvus]. Prieiga internete: <http://link. springer.com/article/10.1177\%2F009207039502300402\#page-1>.

Bivainis, J., Daukševičiūtė, I., Vilkaitė, N. (2011). Ryšių rinkodara per vartotojų lojalumo prizmę. Verslas: teorija ir praktika, Nr. 12 (4): 348-361.

Bivainis, J., Vilkaitè, N. (2010). Vartotojų lojalumo nustatymo metodinio potencialo analizè. Verslas: teorija ir praktika, Nr. 11 (1): 49-60.

Chattananon, A., Trimetsoontorn, J. (2009). Relationship marketing: a Thai case. International Journal of Emerging Markets, Vol. 4, No. 3: 252-274 [interaktyvus]. Prieiga internete: <http://dx.doi. org/10.1108/17468800910968418>.

Coviello, N. E., Brodie, R. J., Munro, H. J. (1997). Understanding contemporary marketing: development of a classification scheme. Journal of marketing management, No. 13: 501-522.

Czepiel, J. A. (1990). Service encounters and service relationships: implications for research. Journal of business research, Vol. 20, No. 1: 13-21.

Damkuvienè, M., Virvilaitė, R. (2007). The Concept of Relationship in Marketing Theory: Definitions and Theoretical Approach. Economics and management, No. 12: 318-325.

Das, K. (2009). Relationship marketing research (1994-2006): an academic literature review. Marketing Intelligence and Planning, Vol. 27, No. 3: 326-363.

Dovalienè, A., Virvilaitè, R. (2003). Santykių marketingo konceptualioji esmè ir ištakos. Inžinerine ekonomika, Nr. 2 (33): 83-94.

Grayson, K., Johnson, D. ir kt. (2008). Is Firm Trust Essential in a Trusted Environment? How Trust in the Business Context Influences Customers. Journal of Marketing Research, No. 4: 241-256. 


\section{Deimena Kiyak, Arina Medvedeva}

Grönroos, Ch. (2004). The relationship marketing process: communication, interaction, dialogue, value. Journal of Business \& Industrial Marketing, Vol. 19, No. 2: 99-113 [interaktyvus]. Prieiga internete: <http://dx.doi. org/10.1108/08858620410523981>.

Gummesson, E. (2007). Exit services marketing-enter service marketing. The Journal of Customer Behaviour, Vol. 6, No. 2: 113-141.

Henning-Thurau, Th., Gwier, K. P., Gremler, D. D. (2002). Understanding relationship marketing outcomes: an integration of relational benefits and relationship quality. Journal of service research, Vol. 4, No. 3: $230-247$.

Yau, O. H. M., Mcfetridge, P. R. et al. (2000). Is relationship marketing for everyone? European Journal of Marketing, Vol. 39, No. 9/10: 1111-1127.

Jucaitytė, I., Maščinskienè, J. (2011). Vertès kūrimas santykių verslas-verslui rinkos kontekste. Ekonomika ir vadyba, Nr. 16: 1259-1265.

Jurgilevičiūtė, L., Sūdžius, V. (2010). Santykių rinkodaros ypatumai teikiant finansines paslaugas. Verslas: teorija ir praktika, Nr. 11 (2): 116-123.

Juščius, V., Grigaite, V. (2009). Santykių marketingo tyrimai logistikos organizacijose: užsienio šalių patirtis. Verslas: teorija ir praktika, Nr. 10 (1): 5-14.

Juščius, V., Grigaitè, V. (2011). Relationship marketing practice in Lithuanian logistics organizations. Baltic Juornal of Management, Vol. 6, No. 1: 71-88.

Juščius, V., Navickas, V. ir kt. (2006). Santykių marketingas: teoriniai aspektai. Verslas: teorija ir praktika, Nr. 4 (7): 254-262.

Kiyak, D. (2013). Produkto vertès sampratos koncepcija kainodaros procese. Regional formation and development studies, Nr. 1 (9): 79-92.

Kotler, Ph., Armstrong, G., Saunder, J. ir kt. (2003). Rinkodaros principai. Kaunas: Poligrafija ir informatika.

Lewicki, R. J., McAllister, D. J. ir kt. (1998). Trust and distrust: new relationships and realities. Academy of Management Review, Vol. 23, No. 3: 438-458.

Morgan, R. M., Hunt, S. D. (1994). The Commitment - Trust Theory of Relationship Marketing. Journal of Marketing, Vol. 58, No. 7: 20-38.

Morris, M. H., Brunyee, J., Page, M. (1998). Relationship marketing in practice: myths and realities. Industrial marketing management, Vol. 27, No. 4: 359-371.

Murphy, P. E., Laczniak, G. R., Wood, G. (2007). An ethical basis for relationship marketing: a virtue ethics perspective. European Journal of marketing, Vol. 41, No. 1: 37-57.

Navickas, V., Malakauskaitè, A. (2009). Tarporganizacinių verslo ryšių formavimosi turizmo sektoriuje prielaidos. Ekonomika ir vadyba, Nr. 14: 863-870.

Olotu, A. O., Maclayton, D. W. ir kt. (2010). An empirical study of relationship marketing orientational and bank performance. Reseach Journal of International Studies, No. 16: 47-57.

Payne, A., Ballantyne, D., Christopher, M. (2005). A stakeholder approach to relationship marketing strategy. European Journal of Marketing, Vol. 39, No. 7/8: 855-871.

Palaima, T., Auruškevičienė, V. (2006). Study of Relationship Quality Dimensionality in the Parcel Delivery Services. Inžinerine ekonomika, Nr. 4 (49): 104-110.

Palmer, A. J. (1996). Relationship marketing: a universal paradigm or management fad? The Learning Organization. MCB University Press, Vol. 3, No. 3: 18-25 [interaktyvus]. Prieiga internete: <http://dx.doi. org/10.1108/09696479610119642>.

Peppers, D., Rogers, M. (1995). A new marketing paradigm: share of customer, not market share. Managing service quality, Vol. 5, No. 3: 48-51.

Pilelienè, L. (2008). Vartotojų lojalumo formavimas: ryšių marketingo aspektai. Vadybos mokslas ir studijos kaimo verslų ir jų infrastruktūros plètrai, Nr. 14 (3): 110-117.

Sheth, J. N., Parvatiyar, A. (2002). Evolving Relationship Marketing into a Discipline. Journal of Relationship Marketing, Vol. 1, No. 1:3-16.

Sin, L. Y. M., Tse, A. C. B. ir kt. (2002). The effect of relationship marketing orientation on business performance in service-oriented economy. Journal of Service Merketing, Vol. 16, No. 7: 656-676. 
Staniulienè, S. (2008). Vadovų galių naudojimas Lietuvos įmonėse jų pavaldinių požiūriu. Organizacijų vadyba: sisteminiai tyrimai, Nr. 48: 121-137.

Sweidan, G., Al-Dmour, H. ir kt. (2012). The effect of relationship marketing on costomer loyality in the Jordanian pharmaceutical industry. European Journal of Economics, Finance and Sciences, No. 53: 154-172.

Vaitkienè, R., Pilibaitytė, V. (2008). Vertės vartotojui kūrimo ir santykių su vartotojais vystymo procesus integruojantis modelis. Taikomoji ekonomika: sisteminiai tyrimai, Nr. 2 (2): 45-57.

Williams, K. C. (2012). Core qualities of successful marketing relationship. Journal of Management and Marketing Research, No. 9: 1-29.

Žvireliené, R. (2005). Santykių rinkodaros esmė ir vieta rinkodaros mokslo kontekste. Ekonomika ir vadyba: aktualijos ir perspektyvos, Nr. 5: 424-428.

Žvirelienė, R., Bučiūnienė, I. (2008). Santykių marketingo dimensijų vaidmuo išlaikant vartotojus. Verslas: teorija ir praktika, Nr. 9 (4): 272-280.

Кущ, С. П. (2003). Сравнительный анализ основных концепций теории маркетинга взаимоотношений. Весник. Серия Менеджмент, No. 32 (4): 3-25.

\section{EXPRESSION OF RELATIONSHIP MARKETING DIMENSIONS}

\section{Deimena Kiyak, Arina Medvedeva}

Summary

Personal health care Higher prices, lack of funding, the need for resourcesaving, rapid patient's wishes and needs growth, constantly increasing competition makes personal health care managers to think about how with lowest cost to remain competitive in the market, not to lose a good institution image, and best meet the current and potential users' expectations. One of the ways to do this - to assess how effective in institutions are subject relationship marketing, the essence of which - the long-term customer relationship development and maintenance. In order to customer loyalty and advantage, all the staff of the institution must have good knowledge of qualitative relations dimensions - basic relations support features. Personal health care institutions relationship with customers must be based on the absolute all institution workers relationship marketing dimensional compliance, which would allow it to move to a higher level of quality and enhance market participants - personal health care institutions and the consumer - the interconnection. Objective of the study - to conclude the relationship between consumers and health care institutions support theoretical model which reveals the relationship marketing features sources and the relationship marketing dimensions mutual link and shaping relationships result.

Relationship marketing and its key dimensions extensive and successful application in institutions are analyzed in many Lithuanian and foreign scientists' 
works, however, they do not take into account the person's health care institutions and patient relationship management specifics. Relationship marketing position in Lithuanian personal care market is not well defined, so it is very important to carry out further research in relationship marketing in this market and to investigate how far relations marketing methods are applied in institutions, what, the real benefit they provide, and what new opportunities for institutions could provide relationship marketing dimensions application.

Relationship marketing concept has evolved exposed self, in different directions carried out researches, therefore the consensus among researchers on the definition of relationship marketing is not reached. Scientists define relationship marketing in different positions: ones examines how consumers' attraction and retention tool, others highlights not only the relationships and support, but also the mutual interaction and promises compliance, while others - only refers to the relationship between supplier and consumer. Relationship marketing can be defined as the attraction of new customers, the relationship between them and institution creation, development, building and, if necessary, the termination for both consumers and the institution's objectives.

The article revealed the following key dimensions of relationship marketing: trust, commitment, mutual dependence, reciprocity, cooperation, power, communication, satisfaction, value, fairness and empathy. It was found that all the elements of relationship marketing are interrelated and influence each other. Trust and commitment - key relationship of marketing dimensions, showing the size and the importance of the existing relationship between the institution and users, but is not specifically clarified, liability is the result of growing confidence or confidence comes from the decision to commit. The value is related to the confidence from the user side. Mutual dependence and commitment associated with mutual agreement, which affects empathy and shows cooperation of both sides. Service institution and consumer interaction formed during collaboration, i.e., the more they interact with each other in accordance with the principles of justice, the stronger their relationship, and the more power has one market participant making another one for him to take the appropriate decision. Communication directly affects confidence and indirectly - commitment.

The compiled relationship between the consumers and health care institutions support theoretical model states that direct impact on customer loyalty in individual health care market has confidence, commitment and satisfaction. Relationship marketing principles - interoperability and power - in personal care market only partially determines the consumer loyalty. 